\title{
Pseudomonas carboxydohydrogena (Sanjieva and Zavarzin) comb. nov., a Monotrichous, Nonbudding, Strictly Aerobic, Carbon Monoxide-Utilizing Hydrogen Bacterium Previously Assigned to Seliberia
}

\author{
ORTWIN MEYER, ${ }^{1}$ JORGE LALUCAT, ${ }^{2}$ AND HANS G. SCHLEGEL' \\ Institut für Mikrobiologie der Universität Göttingen, Grisebachstr. 8, 3400 Göttingen, Federal Republic of \\ Germany, ${ }^{1}$ and Departamento Microbiologia, Fac. Biologia, Universidad de Barcelona, Spain ${ }^{2}$
}

The carbon monoxide-utilizing hydrogen bacterium DSM 1083 (Carboxydobacterium strain Z-1062), the type strain of Seliberia carboxydohydrogena, was found to be a monotrichous, nonbudding, rarely screw-sculptured bacterium which did not convert lactose to 3-ketolactose and which was not pathogenic for tomatoes. Because of these properties and its strictly aerobic metabolism, it is proposed that this organism be transferred from the genus Seliberia to the genus Pseudomonas as Pseudomonas carboxydohydrogena (Sanjieva and Zavarzin) comb. nov. This species is distinctly different from other CO-utilizing pseudomonads with regard to guanosine plus cytosine content, substrate utilization spectrum, and extent of star formation.

To date, only a few bacteria have been described which are able to utilize carbon monoxide aerobically as a sole source of carbon and energy: Hydrogenomonas carboxydovorans (10, 11), Pseudomonas carboxydovorans (18), Seliberia carboxydohydrogena $(20,21,28)$, Pseudomonas carboxydoflava $(27,28)$, Pseudomonas gazotropha $(27,28)$, Comamonas compransoris (27, 28), and Achromobacter carboxydus $(27,28)$.

All carbon monoxide-utilizing bacteria known so far can grow as hydrogen bacteria as well, and they are either nonmotile or motile by means of a polarly or subpolarly inserted flagellum (18, 28 ). With the exception of $S$. carboxydohydrogena, the bacteria of this physiologic group were reported to be pseudomonads or pseudomonadlike organisms $(18,28)$. Electron microscope observations of cells of $S$. carboxydohydrogena never showed budding processes, and clearly spiral cells were rarely encountered. This finding and the strictly respiratory metabolism of $S$. carboxydohydrogena prompted us to investigate the taxonomic position of this organism in detail.

\section{MATERIALS AND METHODS}

Bacterial strain. A culture of the type strain of Seliberia carboxydohydrogena (Carboxydobacterium strains Z-1062 = DSM 1083) was obtained from the Deutsche Sammlung von Mikroorganismen (DSM) immediately after it had been received from G. A. Zavarzin (Institute of Microbiology of the Academy of Sciences, Moscow, USSR). Carboxydobacterium strain Z-1062 was originally designated as the type strain of Seliberia carboxydohydrogena by Sanjieva and Zavarzin (20). Agrobacterium tumefaciens strain 3/3-3 was kindly provided by K. Rudolph (Institut für Pflanzenpathologie, Göttingen, Federal Republic of Germany [FRG]), who received it from Dr. K. Knösel (Institut für Pflanzenpathologie, Stuttgart-Hohenheim, FRG).

Media. The basal medium used for autotrophic growth (22) contained (grams per liter of distilled water): $\mathrm{Na}_{2} \mathrm{HPO}_{4} \cdot 12 \mathrm{H}_{2} \mathrm{O}, 9 ; \mathrm{KH}_{2} \mathrm{PO}_{4}, 1.5 ; \mathrm{NH}_{4} \mathrm{Cl}, 1.0$; $\mathrm{MgSO}_{4}: 7 \mathrm{H}_{2} \mathrm{O}, 0.2$; ammonium ferric citrate, 0.0012 ; $\mathrm{CaCl}_{2} \cdot 2 \mathrm{H}_{2} \mathrm{O}, 0.02$. Trace element solution SL6 of Pfennig ( $1 \mathrm{ml} / \mathrm{liter}$ ) (19), concentrated 10 -fold, was added. For heterotrophic growth, the medium was supplemented with $0.5 \%$ (wt/vol) of the carbon source.

Growth measurements. Turbidity was determined at $436 \mathrm{~nm}$ in a Bausch \& Lomb Spectronic Photometer (diameter $=1 \mathrm{~cm}$ ).

Culture vessels and growth conditions. $S$. carboxydohydrogena was cultivated in a fermentor (10 liters; Braun-Biostat, Melsungen, FRG) and stirred at $500 \mathrm{rpm}$ at $30^{\circ} \mathrm{C}$. The gas mixtures for submerged cultures $\left(40 \% \mathrm{CO}+5\right.$ to $10 \% \mathrm{O}_{2}+55$ to $50 \% \mathrm{~N}$. for autotrophic growth or air for heterotrophic growth) were prepared by using gas pumps (Wösthoff, Bochum, FRG). Carbon monoxide $(99.997 \%$, vol/vol), nitrogen $(99.99 \%$, vol/vol), hydrogen $(99.9 \%$, vol/vol), and oxygen $(99.995 \%$, vol/vol) were obtained from Messer Griesheim GmbH, Düsseldorf, FRG. For heterotrophic growth, the mineral medium was supplemented with $0.5 \%$ of the carbon source.

Electron microscopy. Negative staining was performed with cell samples (immediately adsorbed to carbon films) in each phase of the growth experiment, with $2 \%$ uranylactate as the negative stain (26). A Phillips EM 301 electron microscope was used for observations. For each sample, 300 to 600 cells were counted. 
Phytopathogenicity. Cell material of colonies of Seliberia carboxydohydrogena DSM 1083 and of Agrobacterium tumefaciens 3/3-3 (both heterotrophically grown on agar plates with $0.5 \%$ nutrient broth) was inoculated into the freshly wounded upper stem of 2-week-old tomato plants (Lycopersicon esculentum). Tumor formation was recorded after 14 to 21 days.

3-Ketoglycoside production. The production of 3-ketolactose from lactose was determined by the auxanographic method of Bernaerts and De Ley (3). Cultures of the bacteria investigated were grown in petri dishes at $30^{\circ} \mathrm{C}$ on the basal medium supplemented with $1 \%$ lactose, $0.1 \%$ yeast extract, and $1.4 \%$ agar (Difco Laboratories, Detroit, Mich.). After 3 days of growth, the plates were flooded with a shallow layer of Fehling reagent at room temperature (Fehling I: 7 $\mathrm{g}$ of $\mathrm{CuSO}_{4} \cdot 5 \mathrm{H}_{2} \mathrm{O}$ ) per $100 \mathrm{ml}$ of distilled water; Fehling II: $34 \mathrm{~g}$ of $\mathrm{KNa}$-tartrate and $10 \mathrm{~g}$ of $\mathrm{NaOH}$ per 100 $\mathrm{ml}$ of distilled water; solutions of Fehling I and Fehling II were mixed at a 1:1 ratio before use). If 3-ketolactose was produced by the bacteria tested, a yellow ring of $\mathrm{Cu}_{2} \mathrm{O}$ became visible around the colonies.

Nutritional properties. Substrate utilization tests were performed on solid media ( $1.4 \%$ agar; Difco) in the presence of $0.2 \%$ of the carbon source. Growth was recorded visually after 5,8 , and 12 days. In those cases where the growth on plates was ambiguous, growth experiments were conducted in liquid culture.

Methods for determining biochemical features. The hydrolysis of starch, urea, exogenous poly$\beta$-hydroxybutyric acid, agar, and Tween 80 , the Gram reaction, and the presence of oxidase and catalase were determined by the procedures described by Cowan (4). The relationship of growing cells to oxygen and anaerobic growth in stab cultures (basal medium, with $1.4 \%$ agar) supplemented with nutrient broth $(0.1 \%)$-yeast extract $(0.1 \%)$ and glucose $(0.1 \%)$ or fructose $(0.1 \%)$ were also tested.

\section{RESULTS}

Cells of Seliberia carboxydohydrogena DSM 1083 were found to be gram-negative, colorless, motile, and catalase and oxidase positive. Starch, urea, exogenous poly- $\beta$-hydroxybutyric acid, agar, and Tween 80 were not hydrolyzed. The bacterium was avirulent for Lycopersicon esculentum and was 3-ketolactose-negative whereas the control organism, Agrobacterium tumefaciens $3 / 3-3$, showed tumor formation as well as 3-ketolactose production. Neither meta-hydroxybenzoate nor pantothenate was used as a sole source of carbon. In stab cultures supplemented with nutrient broth-yeast extract, glucose, or fructose, growth of $S$. carboxydohydrogena DSM 1083 occurred exclusively on the agar surface, indicating that growth was strictly dependent on the presence of oxygen.

The substrate utilization spectrum of $S$. carboxydohydrogena DSM 1083 was restricted. Only acetate, pyruvate, lactate, citrate, fumarate, malate, and aspartate were used as sole

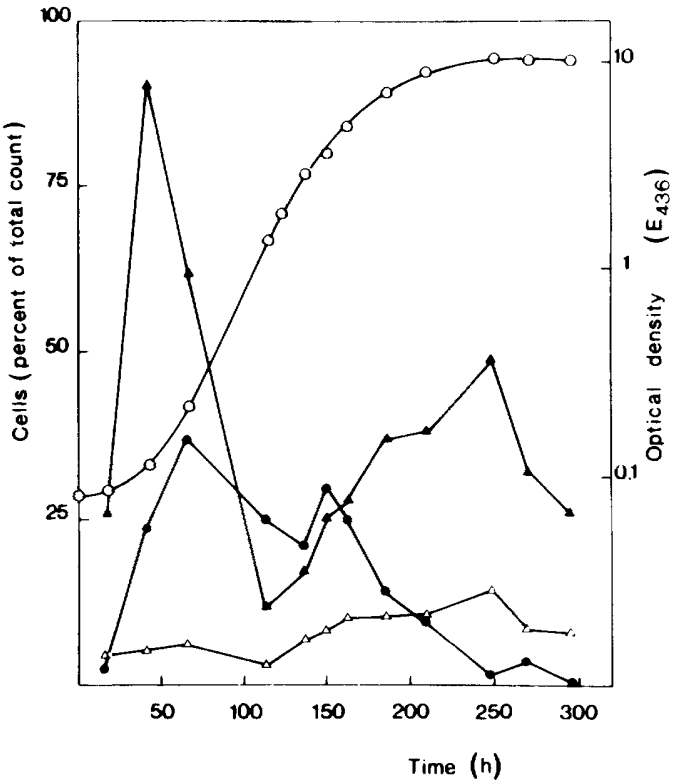

FIG. 1. Variation of flagellation and aggregation of Pseudomonas carboxydohydrogena during CO-autotrophic growth. Optical density $\mathrm{E}_{4: 36}^{1 \mathrm{~cm}}(\mathrm{O})$; cells with only one flagellum $(\mathrm{)})$, number of aggregates $(\triangle)$, number of aggregated cells $(\boldsymbol{\Delta})$. Values are given in percent cells of the total cell number. Each point represents the evaluation of 300 to 600 cells on negatively stained preparations. The percentage of spirally twisted cells was always below 3.5\%.

sources of carbon and energy for heterotrophic growth. With the exception of fructose, sucrose, and aspartate, carbohydrates and amino acids, as well as $m$-hydroxybenzoate and pantothenate, were not utilized. The cells were able to grow autotrophically in a mineral medium under an atmosphere of $40 \% \mathrm{CO}, 10 \% \mathrm{O}_{2}$, and $50 \% \mathrm{~N}_{2}$ at a doubling time $\left(t_{d}\right)$ of $20 \mathrm{~h}\left(30^{\circ} \mathrm{C}\right)$ as well as under an atmosphere of $80 \% \mathrm{H}_{2}, 10 \% \mathrm{O}_{2}$, and $10 \% \mathrm{CO}_{2}\left(t_{d}=7 \mathrm{~h}\right)$. The enzyme system for carbon monoxide utilization was soluble and was formed only during growth with $\mathrm{CO}$; hydrogenase was membrane bound and was present in cells grown with $\mathrm{CO}$ or with $\mathrm{H}_{2}+\mathrm{CO}_{2}$.

When Seliberia carboxydohydrogena DSM 1083 was grown in liquid batch culture with carbon monoxide as a sole carbon and energy source, changes in flagellation, number of aggregates, and number of aggregated cells were observed (Fig. 1, 2, and 3). During transition from the lag to the log phase, almost all cells (about 90\%) were found to be present as aggregates. The ratio of the aggregates to the total number of cells was small, indicating that the transition phase was characterized by large clusters of stellate aggregations consisting of up to 30 cells (Fig. 


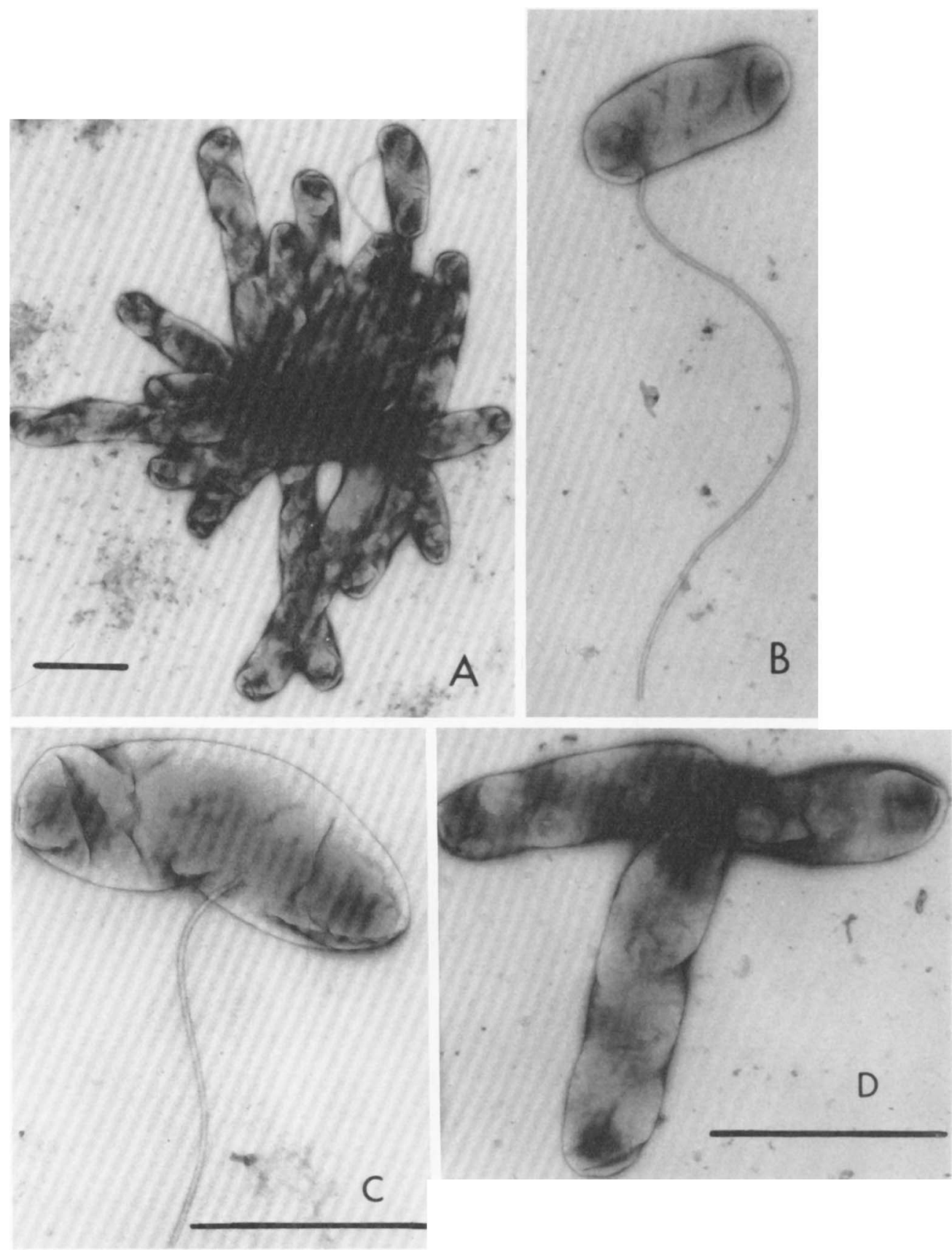

FIG. 2. Cells taken at different growth phases from a CO-autotrophically grown culture of Pseudomonas carboxydohydrogena. (A) Cell clusters from the transition of the lag- to the log-phase, containing a large number of cells. (B) Monotrichous cells from the beginning of the exponential growth phase. (C) Cells showing a tendency to subpolar insertion of flagella. (D) Small cell clusters from the transition of exponential to stationary growth phase. Each bar represents $1 \mu \mathrm{m}$.

1 and 2A). At the beginning of the exponential growth phase, the number of aggregates decreased. The cells were motile by means of a single, subpolarly inserted flagellum (Fig. 2B), and only a few cells were observed with laterally inserted flagella (Fig. 2C). Up to $37 \%$ of all of the cells counted were monotrichous (Fig. 1); only 2 of about 10,000 cells counted have been 

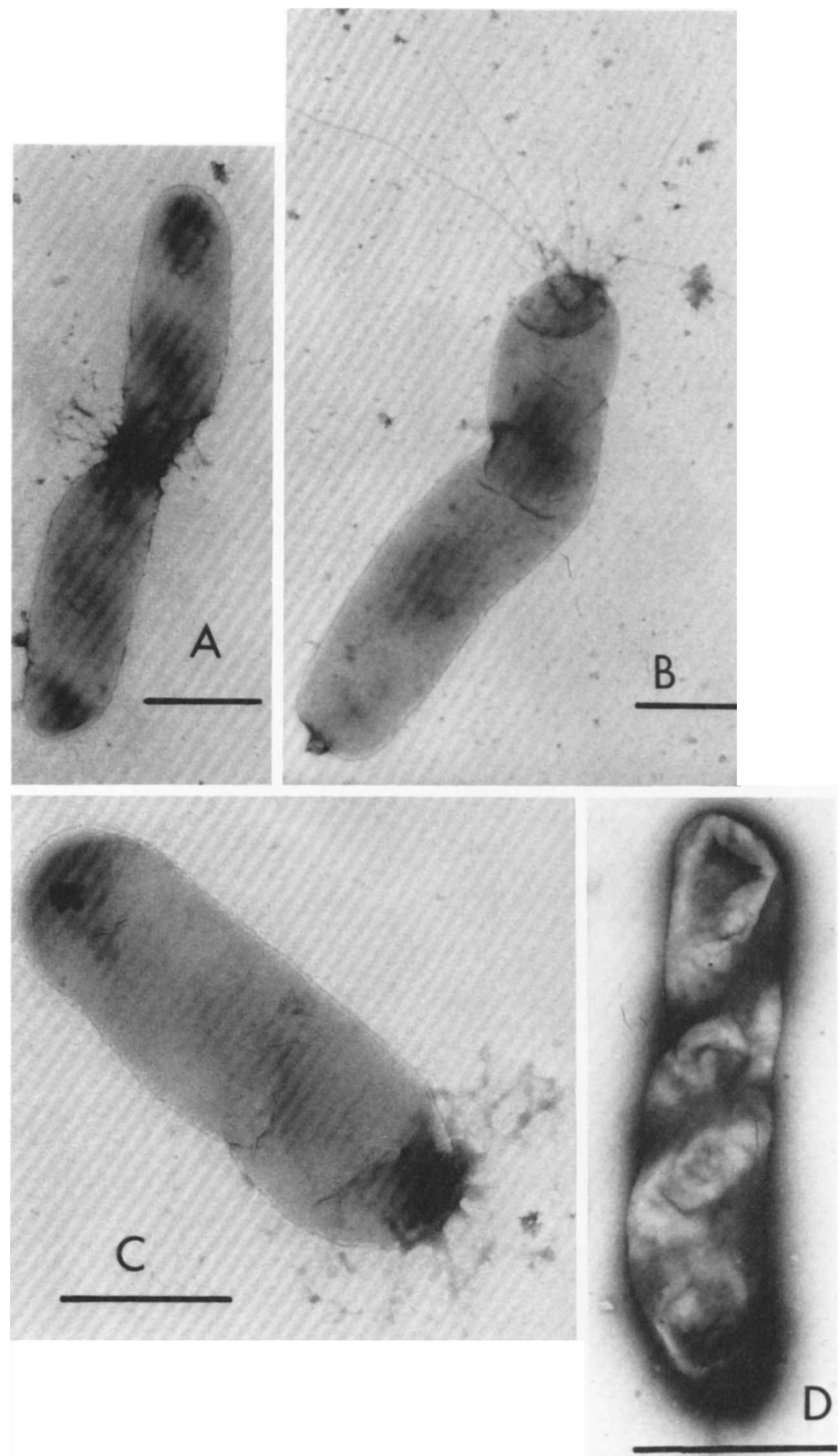

FIG. 3. Selected cells from various stages of the CO-autotrophically grown culture of P. carboxydohydrogena. (A) Two cells connected by a slime bridge. (B) Polar fimbriae. (C) Cell with polarly excreted slime. (D) Cell with a twisted (screw-sculptured) surface; less than $3.5 \%$ of the cells are of this shape. Each bar represents $0.5 \mu \mathrm{m}$. 
observed to contain two subpolar flagella. The exponential growth phase itself was characterized by a high number of flagellated cells (between 20 and $37 \%$ of the total cell count), by a decrease in the number of aggregated cells (from 90 to $12 \%$ ), and by a large number of small aggregates consisting of only two or three cells (Fig. 2D and 3A). During the transition from the exponential to the stationary growth phase (Fig. 1), motility of the cells decreased and aggregation started again. As indicated by the increasing number of aggregated cells and stellate aggregations, the clusters were rather small (Fig. 2D and $3 \mathrm{~A}$ ). In the stationary growth phase, the number of flagellated cells was almost zero; the number of aggregated cells decreased again (from 49 to $25 \%$ ), and the number of stellate aggregates remained approximately constant (Fig. 1).

The number of cells with a screw-sculptured surface never exceeded $3.5 \%$ of the total cell number (Fig. 3D); the surface of most cells was smooth (Fig. 2B and C and 3A, B, and C).

During heterotrophic growth with L-malate, no screw-sculptured cells were found, and maximally $10 \%$ of the cells were aggregated. On the other hand, $85 \%$ of the cells were found to be monotrichous (Fig. 2B). Neither CO autotrophically grown nor heterotrophically (L-malate) grown cells showed budding in any growth phase. The cells always multiplied by normal binary transverse fission; this was also found to be the case for cells grown on solid media with nutrient broth or pyruvate as substrate.

\section{DISCUSSION}

As noted elsewhere $(18,28)$, the majority of aerobic $\mathrm{CO}$-utilizing bacteria studied so far are either nonmotile or motile by means of a polarly or subpolarly inserted flagellum. They are gram negative, their metabolism is strictly aerobic, and they can grow under conditions suitable for hydrogen bacteria.

As described in the current edition of Bergey's Manual (2), the genus Seliberia comprises rodshaped, spirally twisted cells (ranging from 0.50.7 by $1-12 \mu \mathrm{m}$ ), which form star-shaped figures or rosettes. The cells multiply by transverse fission and by budding. When grown on soil media, round to ovoid "generative" cells are formed. Resting stages are not known. The Gram reaction and the guanosine plus cytosine $(\mathrm{G}+\mathrm{C})$ content were not reported. The metabolism is chemoorganotrophic, and organic growth factors are not required. The cells are facultatively anaerobic (2).

In contrast to the description of Seliberia in Bergey's Manual (2), it was reported previously
$(21,28)$ that the metabolism of Seliberia car boxydohydrogena is strictly aerobic and oxidative and that carbohydrates are not fermented. This was confirmed by our observations. Furthermore, budding has never been observed in this organism, and cells with a screw-sculpticed surface were rarely encountered during $\mathrm{CO}$-autotrophic growth and were never found during heterotrophic growth with L-malate, pyruvate, or nutrient broth. With respect to the properties discussed, strain DSM 1083 must be excluded from the genus Seliberia.

According to Bergey's Manual (1), the genus Agrobacterium comprises rod-shaped cells (0.8 by 1.5 to 0.8 by $3.0 \mu \mathrm{m}$ ) which are motile by means of one to four nonpolar flagella; if only one flagellum is present, lateral attachment is more common than polar. The cells are gram negative and nonsporeforming, and fimbriae are common. Growth on carbohydrate-containing media is usually accompanied by copious extracellular polysaccharide slime. Colonies are not pigmented. The metabolism is respiratory, and molecular oxygen is the terminal electron acceptor. 3-Ketolactose is commonly produced. Members of this genus initiate stem hypertrophies on diverse plants wherein the bacteria occur as intercellular parasites. Bacteria enter host tissue through preexisting lesions or abrasions; the ability to invade host plant tissue directly is lacking. Tissue puncture inoculation tests are essential to confirm strain identification based on routine biochemical tests. The $\mathrm{G}+\mathrm{C}$ content of the deoxyribonucleic acid ranges from 59.6 to $62.8 \mathrm{~mol} \%$.

According to the improved taxonomy of the genus Agrobacterium given by De Ley et al. (6), all strains of this genus proper are peritrichous (five to six flagella). Frequently, 2 to 10 cells stick together, and the occurrence of single cells is rare. One or two of the flagella were often subpolarly inserted. All 8 strains of $A$. radiobacter and 24 of the 28 strains of the variety "tumefaciens" tested converted lactose into 3 ketolactose.

In contrast, the cells of $S$. carboxydohydrogena DSM 1083 are monotrichous, 3-ketolactose negative, and nonpathogenic to Lycopersicon esculentum; therefore strain DSM 1083 must be excluded from the genus Agrobacterium.

On the basis of its distinctly monotrichous character, strain DSM 1083 cannot be assigned to the genus Alcaligenes. This conclusion is supported by the inability of DSM 1083 to grow with either $m$-hydroxybenzoate or pantothenate as a sole carbon source; among the hydrogen autotrophs, this is a feature of the pseudomonads, not of species of Alcaligens $(5,7)$. The 
genus Pseudomonas comprises gram-negative, singly occurring, straight or curved but not helical rods. The cells are predominantly monotrichous, sometimes with a tendency to subpolar insertion (7). The metabolism is respiratory, never fermentative. Some are facultatively chemolithotrophic, able to use hydrogen or carbon monoxide as an energy source. Molecular oxygen is the universal electron acceptor; some can denitrify. The $\mathrm{G}+\mathrm{C}$ content of the deoxyribonucleic acid ranges from 58 to $70 \mathrm{~mol} \%$ (5).

The G+C content of strain DSM 1083 (58.2 $\mathrm{mol} \%)$ is within the range of the pseudomonads. The nutritional requirements of strain DSM 1083 are simple and no growth factors are required. Starch, urea, exogenous poly- $\beta$-hydroxybutyric acid, agar, and Tween 80 are not hydrolyzed, catalase and oxidase are produced, and the organism is able to use hydrogen as well as carbon monoxide as an energy source.

With respect to its physiological properties, strain DSM 1083 completely agrees with the description of Pseudomonas given in Bergey's Manual (7). The only ambiguous property pertains to morphology: the flagellum of DSM 1083 is in most cases subpolarly inserted. The assignment of this strain to Pseudomonas is a result of its exclusion from other gram-negative monoor multitrichous genera and its high degree of resemblance to pseudomonads with respect to basic metabolic features. It should be emphasized that it is often difficult to draw clear lines of distinction between polar, subpolar, and degenerately nonpolar flaggelation; both number and mode of insertion of the flagella may vary with individual cells in a given culture. These characteristics often change with the conditions of cultivation.

DSM 1083 is distinctly different from the other CO-utilizing pseudomonads with respect to the extent of star formation, the substrate utilization spectrum, the form and color of colonies, and the $\mathrm{G}+\mathrm{C}$ content of the deoxyribonucleic acid (Seliberia carboxydohydrogena DSM 1083, 58.2; P. carboxydovorans, $60.7 ; P$. carboxydoflava, 63.7; P. gazotropha, 66.9 ; Comamonas compransoris, 56.0; Archromobacter carboxydus, 48.6 [ $\mathrm{G}+\mathrm{C}$ values in moles percent]), as previously reported (28). The $\mathrm{G}+\mathrm{C}$ contents of the DNAs of Seliberia carboxydohydrogena and Pseudomonas carboxydovorans are very similar. However, in contrast to $P$. carboxydovorans, DSM 1083 is able to grow on sugars like fructose and sucrose and has a pronounced tendency to grow in the form of stellate aggregations in liquid media under autotrophic conditions.

The formation of stellate aggregates, which is not typical for members of the genus Seliberia, has been reported for species and strains of other genera: Agrobacterium tumefaciens $(24,25)$, Agrobacterium radiobacter $(24,25)$, Agrobacterium stellatum $(24,25)$, Rhizobium lupini $(9$, 13 ), the coryneform hydrogen bacterium Xanthobacter autotrophicus strain $14 \mathrm{~g}(23)$, the pseudomonads $P$. rhodos $(12,16)$ and $P$. echinoides $(8,12,15,17)$, and an unidentified strain (14). On the basis of the arguments considered, it is proposed that strain DSM 1083 (Carboxy. dobacterium Z-1062) be transferred to the genus Pseudomonas; the name of this organism thus becomes Pseudomonas carboxydohydrogena (Sanjieva and Zavarzin) comb. nov.

\section{ACKNOWLEDGMENT}

We thank K. Rudolph for his advice on the method for testing for phytopathogenic properties.

\section{REPRINT REQUESTS}

Address reprint requests to: Prof. Dr. H. G. Schlegel, Institut für Mikrobiologie, Grisebachstrasse 8, 3400 Göttingen, Federal Republic of Germany.

\section{LITERATURE CITED}

1. Allen, O. N., and A. J. Holding. 1974. Genus II. Agro bacterium Conn 1942, 359. Nam. gen. cons. Opin. 33 Jud. Comm. 1970, 10, p. 264-267. In R. E. Buchanan and N. E. Gibbons (ed.), Bergey's manual of determinative bacteriology, 8th ed., The Williams \& Wilkins Co., Baltimore.

2. Aristovskaya, T. V. 1974. Genus Seliberia Aristovskaya and Parinkina 1963, 56, p. 160. In R. E. Buchanan and N. E. Gibbons (ed.), Bergey's manual of determinative bacteriology, 8 th ed. The Williams \& Wilkins Co., Baltimore.

3. Bernaerts, M. J., and J. De Ley. 1963. A biochemical test for crown gall bacteria. Nature (London) 197:406407.

4. Cowan, S. T. 1974. Cowan and Steel's manual for the identification of medical bacteria. 2nd ed. Cambridge University Press, New York.

5. Davis, D. J., M. Doudoroff, and R. Y. Stanier, and M. Mandel. 1969. Proposal to reject the genus Hydrogen. omonas: taxonomic implications. Int. J. Syst. Bacteriol. 19:375-390.

6. De Ley, J., M. Bernaerts, A. Rassel, and J. Guilmot. 1966. Approach to an improved taxonomy of the genus Agrobacterium. J. Gen. Microbiol. 43:7-17.

7. Doudoroff, M., and N. J. Palleroni. 1974. Family I. - Pseudomonaadaceae Winslow, Broadhurst, Buchanan, Krumwiede, Rogers and Smith, 1917, 555, p. 217-253. In R. E. Buchanan and N. E. Gibbons (ed.), Bergey's manual of determinative bacteriology, 8 th ed., The Williams \& Wilkins Co., Baltimore.

8. Heumann, W. 1968. Conjugation in starforming Rhizobium lupini. Mol. Gen. Genet. 102:132-144.

9. Heumann, W., and R. Marx. 1964. Feinstruktur und Funktion der Fimbrien bei dem sternbildenden Bakterjum Pseudonomonas echinoides. Arch. Mikrobiol. 47: 325-337.

10. Kistner, A. 1953. On a bacterium oxidizing carbon monoxide. Proc. K. Ned. Akad. Wet. Ser. C 56:443-450.

11. Kistner, A. 1954. Conditions determining the oxidation of carbon monoxide by Hydrogenomonas carboxydovorans. Proc. K. Ned. Akad. Wet. Ser. C 57:186-195.

12. Marx, R., and W. Heumann. 1962. Über Geißel- 
feinstrukturen und Fimbrien bei zwei PseudomonasStämmen. Arch. Mikrobiol. 43:245-254.

13. Mayer, F. 1969. Die Fimbrien von Rhizobium lupini $1 / 50$ sta $^{-}$, Arch. Mikrobiol. 68:179-196.

14. Mayer, F. 1970. Elektronenmikroskopische Untersuchungen der Zellverbindung bei einem sternbildenden Bakterium. Z. Allg. Mikrobiol. 10:329-334.

15. Mayer, F. 1971. Elektronenmikroskopische Untersuchungen der Fimbrienkontraktion bei dem sternbildenden Bodenbakterium Pseudomonas echinoides. Arch. Mikrobiol. 76:166-173.

16. Mayer, F., S. Kall, and R. Schmitt. 1974. Untersuchung der morphologischen Grundlagen für einen möglichen Übertragungsweg der DNA bei der Konjugation sternbildender Bodenbakterien. Z. Allg. Mikrobiol. 14:221228.

17. Mayer, F., and R. Schmitt. 1971. Elektronenmikroskopische, diffraktometrische und disc-electrophoretische Untersuchungen an Fimbrien des stembildenden Bodenbakteriums Pseudomonas echinoides und einer nicht-sternbildenden Mutante. Arch. Mikrobiol. 79: $311-326$.

18. Meyer, O., and H. G. Schlegel. 1978. Reisolation of the carbon monoxide utilizing hydrogen bacterium Pseudomonas carboxydovorans (Kistner) comb. nov. Arch. Microbiol. 118:35-43.

19. Pfennig, N. 1974. Rhodopseudomonas globiformis, sp.n., a new species of the Rhodospirillaceae. Arch. Microbiol. 100:197-206.

20. Sanjieva, E. U., and G. A. Zavarzin. 1971. Oxidation of carbon monoxide by Seliberia carboxydohydrogena. Dokl. Akad. Nauk SSSR 196:956-958.

21. Savalieva, N. D., and A. N. Nozhevnikova. 1972. Autotrophic growth of Seliberia carboxydohydrogena during oxidation of hydrogen and carbon monoxide. Mikrobiologiya 41:813-817.

22. Schlegel, H. G., H. Kaltwasser, and G. Gottschalk. 1961. Ein Submersverfahren zur Kultur wasserstoffoxydierender Bakterien: Wachstumsphysiologische Untersuchungen. Arch. Mikrobiol. 38:209-222.

23. Schneider, K., V. Rudolph, and H. G. Schlegel. 1973. Description and physiological characterization of a coryneform hydrogen bacterium, strain 14g. Arch. Mikrobiol. 93:179-193.

24. Stapp, C., and D. Knösel. 1956. Phasenoptisch-cytologische Untersuchungen sternbildender Bakterien. Zentralbl. Bakteriol. Parasitenkd. Infektionskr. Hyg. Abt. 2 109:25-41.

25. Stapp, C., and D. Knösel. 1956. Fortgeführte Untersuchungen über den Entwicklungscyclus und die Karyologie sternbildender Bakterien. Zentralbl. Bakteriol. Parasitenkd. Infektionskr. Hyg. Abt. 2 109:416-428.

26. Valentine, R. C., B. M. Shapiro, and E. R. Stadtman. 1968. Regulation of glutamine synthetase. XIII. Electron microscopy of the enzyme from $E$. coli. Biochemistry $7: 2143-2152$.

27. Zavarzin, G. A. 1974. Phenotypic taxonomy. Space of logic possibilities. Nauka Publishing House, Moscow.

28. Zavarzin, G. A., and A. N. Nozhevnikova. 1977. Aerobic carboxydobacteria. Microb. Ecol. 3:305-326. 